\title{
Science, Technology, Engineering, and Mathematics Education for Sustainable Energy in Wetland Environment
}

\author{
Eko Susilowati \\ Physics Education Study Program FKIP \\ Universitas Lambung Mangkurat \\ Banjarmasin, Indonesia \\ titis_pfis@ulm.ac.id \\ Suyidno \\ Physics Education Study Program FKIP \\ Universitas Lambung Mangkurat \\ Banjarmasin, Indonesia \\ T Mayasari \\ Physics Education Study Program PMIPA \\ Universitas PGRI Madiun \\ Madiun, Indonesia
}

\author{
Zainuddin \\ Physics Education Study Program FKIP \\ Universitas Lambung Mangkurat \\ Banjarmasin, Indonesia \\ Arif Sholahuddin \\ Chemistry Education Study Program FKIP \\ Universitas Lambung Mangkurat \\ Banjarmasin, Indonesia
}

\author{
S Miriam \\ Physics Education Study Program FKIP \\ Universitas Lambung Mangkurat \\ Banjarmasin, Indonesia \\ $\mathrm{N}$ Winarno \\ Science Education Study Program \\ Universitas Pendidikan Indonesia \\ Bandung, Indonesia
}

\begin{abstract}
Creativity is a competency that must be mastered by students based on 21st-century learning skill standards in accordance with the development of science and technology. This requires students to become active, creative and innovative human beings in responding to increasingly complex and diverse global challenges. This study aims to determine the level of creativity of students in integrating knowledge of Science Technology Engineering and Mathematics (STEM) with the theme of renewable energy. This research was conducted at one of the Teacher Training Institutions in Banjarmasin with a total of 46 students who programmed applied for science courses. This study uses qualitative and quantitative methods by exploring the dimensions of student creativity to enhance student creativity. The results showed that the dimensions of student creativity are influenced by STEM learning which can support student creativity by elaborating knowledge, skills, and abilities in solving problems in daily life.
\end{abstract}

Keywords: exploration, creativity, integration, STEM

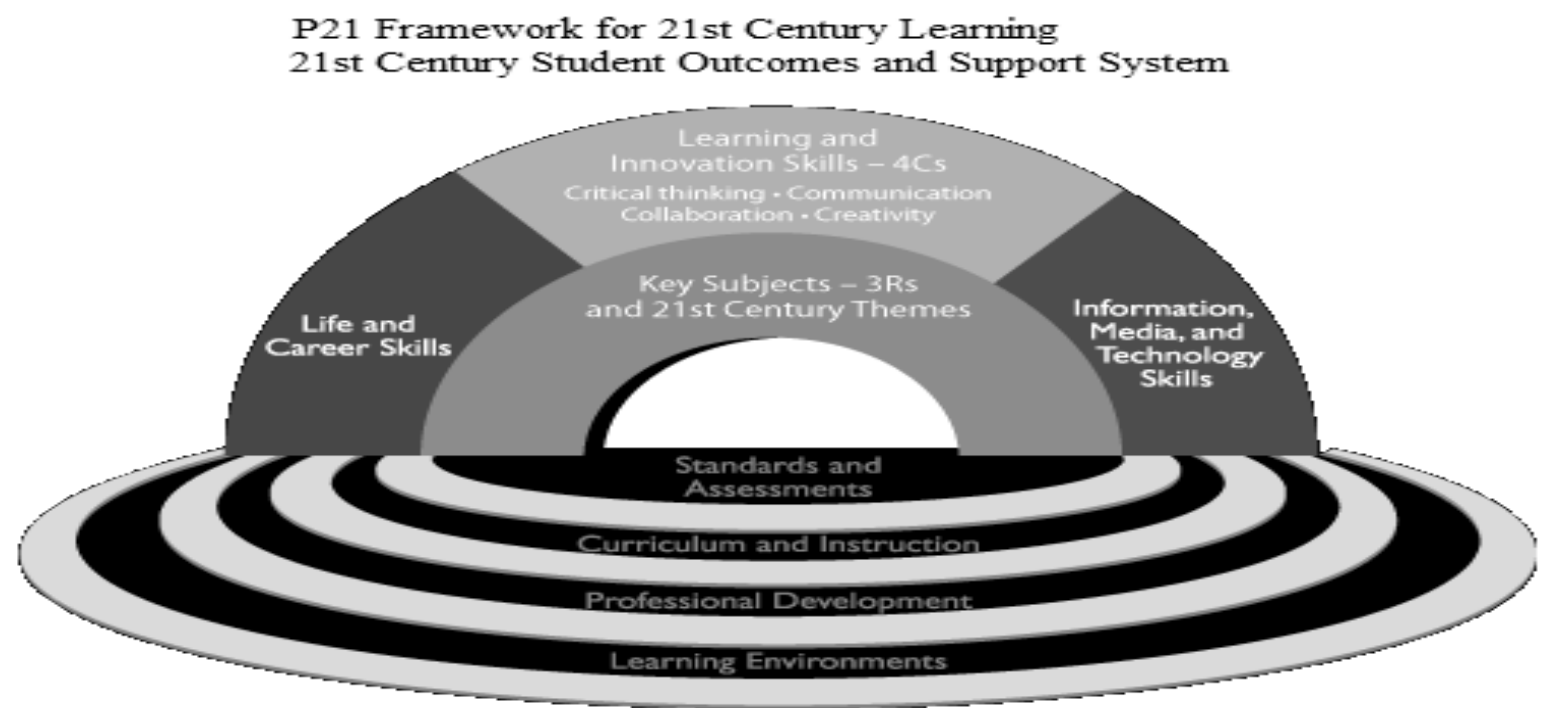

Copyright () 2020 The Authors. Published by Atlantis Press SARL. 
energy.

The main competencies needed to face the future are creativity, communication, flexibility, and independence [34]. Therefore, the education curriculum in Indonesia seeks to produce students who master the competencies needed in the 21 st century through the development of creative education in realizing "Creative Indonesia 2045". However, this has not been supported by learning in Indonesia which still relies on memorization with teaching that is still conventional [5]. This causes students' creativity not to develop properly.

The integration of Knowledge Science, Technology, Engineering, and Mathematics needs to be used in the learning process [6 - 7]. The teacher designs STEM-based learning to improve the ability to solve problems and make decisions [8]. STEM can develop students' creativity to solve real-life problems. Students can understand and apply STEM more meaningfully.

This study aims to explore the dimensions of student creativity through the integration of STEM knowledge. The model is Project-Based Learning used to explore creative products as a result of students working on projects. This study answers research questions consisting of: (1) How is student creativity through the integration of STEM knowledge ?, (2) what is the level of student creativity based on a review of the creativity dimension?.

\section{METHOD}

Creativity is not a talent. Inheritance inherited from parents. Creativity can be trained and developed to explore the potential of students through the learning process [9]. This study involved 46 prospective physics teachers who programed Applied Physics in one of the LPTKs in Banjarmasin. This course is carried out with a weight of 2 credits during 16 meetings through six stages of learning as shown in Table I.

TABLE I. STAGES OF LEARNING ACTIVITy STAGES

\begin{tabular}{|c|c|}
\hline Stage & Activity \\
\hline 1 & Identifying Problems \\
\hline 2 & Exploring Problems \\
\hline 3 & Formulating and Analyzing Ideas \\
\hline 4 & Designing Project Designs \\
\hline 5 & Making and Testing Projects \\
\hline 6 & Reporting Project Results \\
\hline
\end{tabular}

Students are guided to recognize the condition of the energy crisis that occurred in Indonesia in particular to explore the energy problems that occur in their environment and are directed to solve these problems through the empowerment of renewable energy. Through this activity, students participate actively and contribute through the theme of renewable energy by creating creative products through the integration of STEM. Students are divided into 10 groups with different projects. The projects are chosen by each group based on the identification and exploration of problems that occur in the surrounding environment with the theme of renewable energy. The projects undertaken include solar cell energy, wind energy, water energy, and wetland
The research method used is a mixed-method (qualitative and quantitative [10]. Quantitative data is obtained from tests of creativity, tests of energy concepts, and assessment of creative products. Qualitative data is collected through interviews, questionnaires, responses, and student journals. The validity is calculated using the Content Validity Ratio (CVR) [11] Then a paired t-test is performed to determine the effectiveness of the integration of STEM knowledge on the dimensions of student creativity.

\section{RESULTS AND DISCUSSION}

The results of the study are discussed into two sections that answer the research questions. The first part explains how student creativity through STEM knowledge integration and the second part explains how the level of student creativity based on a review of the creativity dimension 1 . The creative thinking ability test was carried out before and after learning (initial and final tests) to find out whether the integration of STEM knowledge can increase student creativity. Students' creative thinking abilities consist of four indicators namely fluency, flexibility, originality, and elaboration [12 - 13]. Paired t-test results of the dimensions of student creativity for each indicator consisting of components of fluency, flexibility, originality, and elaboration can be seen in Table II.

TABLE II. T-TEST RESULTS OF THE DIMENSIONS OF STUDENT CREATIVITY

\begin{tabular}{|c|c|c|c|}
\hline Subject & $\begin{array}{l}\text { Pre- } \\
\text { test/Pos- } \\
\text { test }\end{array}$ & $\begin{array}{l}\text { Paired } \\
\text { Differences } \\
\text { M (SD) }\end{array}$ & $\mathrm{T}$ \\
\hline \multirow[t]{2}{*}{ Fluency } & Pair 1 & 4.147 & $7.542 * * *$ \\
\hline & Flu-pFlu & $(2.985)$ & \\
\hline \multirow[t]{2}{*}{ Flexibility } & Pair 2 & 4.611 & $11.168 * * *$ \\
\hline & Fle-pFle & $(2.263)$ & \\
\hline \multirow[t]{2}{*}{ Originality } & Pair 3 & 3.280 & $6.773 * * *$ \\
\hline & Ori-pOri & $(2.636)$ & \\
\hline \multirow[t]{2}{*}{ Elaboration } & Pair 4 & 2.825 & $5.741 * * *$ \\
\hline & Ela-pEla & $(2.662)$ & \\
\hline
\end{tabular}

Figure 2 shows the average percentage of indicators of students' creative thinking skills during pre-test and post- test that shows an increase.

Indicators of fluency in creative thinking skills have increased by $18 \%$, flexibility by $20 \%$, originality by $16 \%$, and elaboration by $15 \%$. Based on these results it can be stated that learning through the integration of STEM knowledge can increase the dimensions of student creativity. In the activity of identifying problems, exploring problems, formulating and analyzing ideas, the dimensions of student creativity on flexibility $(\mathrm{t}=11,168$; $\mathrm{p}<0,001)$, and fluency $(\mathrm{t}=7,542 ; \mathrm{p}<0,001)$ showed a good development. Students are able to identify the problem of energy crisis by offering many creative solutions. 


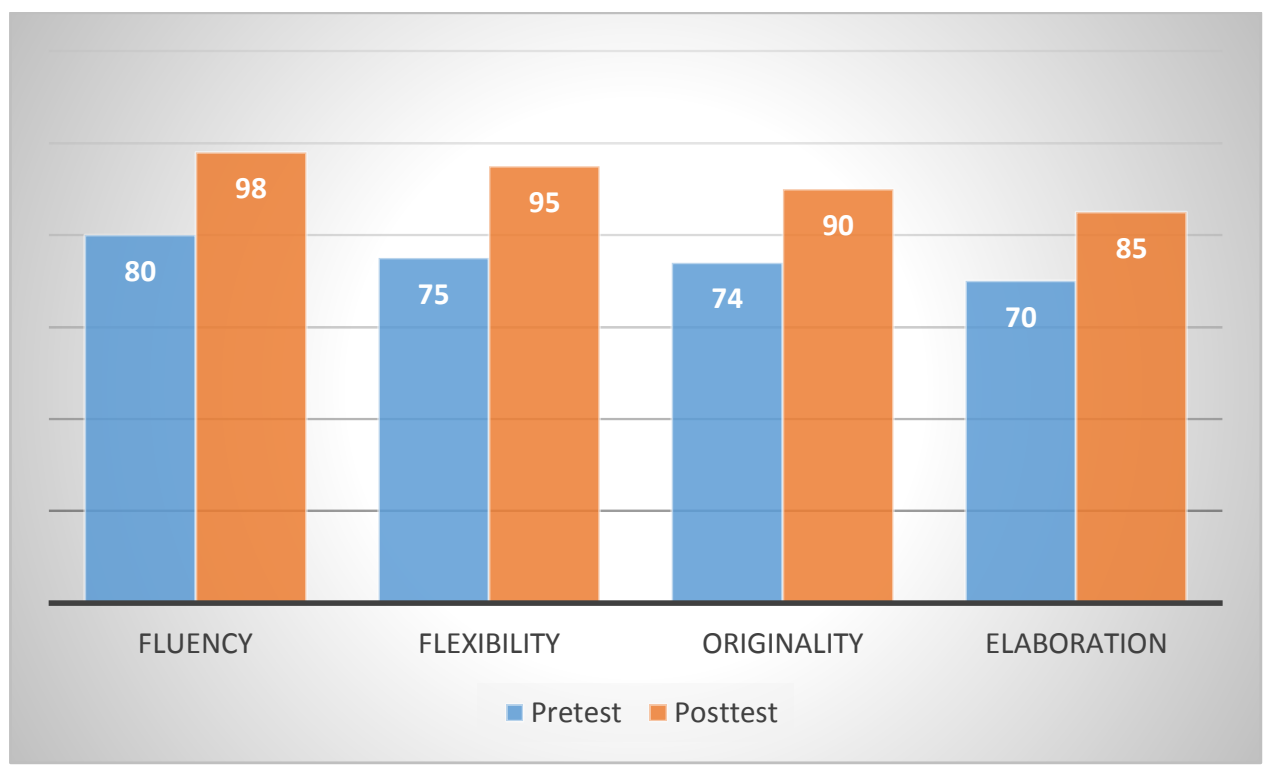

Fig. 2. The average percentage of pretest and posttest creative thinking abilities

The next step is to design and create a project design to realize the ideas that have been analyzed. Students learn to identify problems, offer alternative solutions, and design projects through the integration of STEM knowledge with a variety of creativity. During the project design activity, the group that designed the hydroelectric power plant revised the design of the project it had designed. At the beginning of making advice power plant hydro floating, the turbine used came from zinc, but after testing the zinc material was too heavy to form into a system. Therefore, it is replaced by material polycarbonate which is lighter than zinc. Then, the use of bearings supported the rotation of the turbine. The wheel system also initially used gear for small wheels and plates for large wheels, but due to the availability of size variations bearing, it was changed to use pulleys made of wood that can be formed according to the appropriate size, the use of wood pulleys also tends to be lighter so such system turnover tends to be smoother. If you use gears and discs as wheels the ropes are used to interconnect the wheels, namely chains. However, because the wheels use wood pulleys, the ropes used are pulleys which in this tool use long ropes made of rubber. Ropes are made from rubber because the coefficient of friction owned by rubber-type material is large enough so that no slip occurs when the wheels spin. This shows that students have collaborated to solve problems well. This success is a series of activities and experiences done by students learning from failure. Student learning activities through STEM integration can be explained as in Figure 3.

TABLE III. INTEGRATED LEARNING ACTIVITIES STEM KNOWLEDGE

\begin{tabular}{|c|c|}
\hline Activity & STEM knowledge integration activities \\
\hline $\begin{array}{l}\text { Konsumsil listrik yang semakin meningkat } \\
\text { Mengurangi pencemaran udara akibat } \\
\text { penggunaan bahan bakar fosil } \\
\text { Memantatatakn kekayaar lokal berupa } \\
\text { sungai di i sekitar massararakat }\end{array}$ & $\begin{array}{l}\text { Science } \\
\text { In terms of science namely energy used in this tool is } \\
\text { the kinetic energy of running water. Due to the } \\
\text { effects of high and low tides, river water can flow. } \\
\text { Unlike the water flowing in mountainous areas } \\
\text { whose flow from upstream to downstream. However, } \\
\text { this flow is due to high tides and tides. Then, the } \\
\text { kinetic energy of this river flow is used to produce } \\
\text { electricity. } \\
\text { Technology }\end{array}$ \\
\hline
\end{tabular}




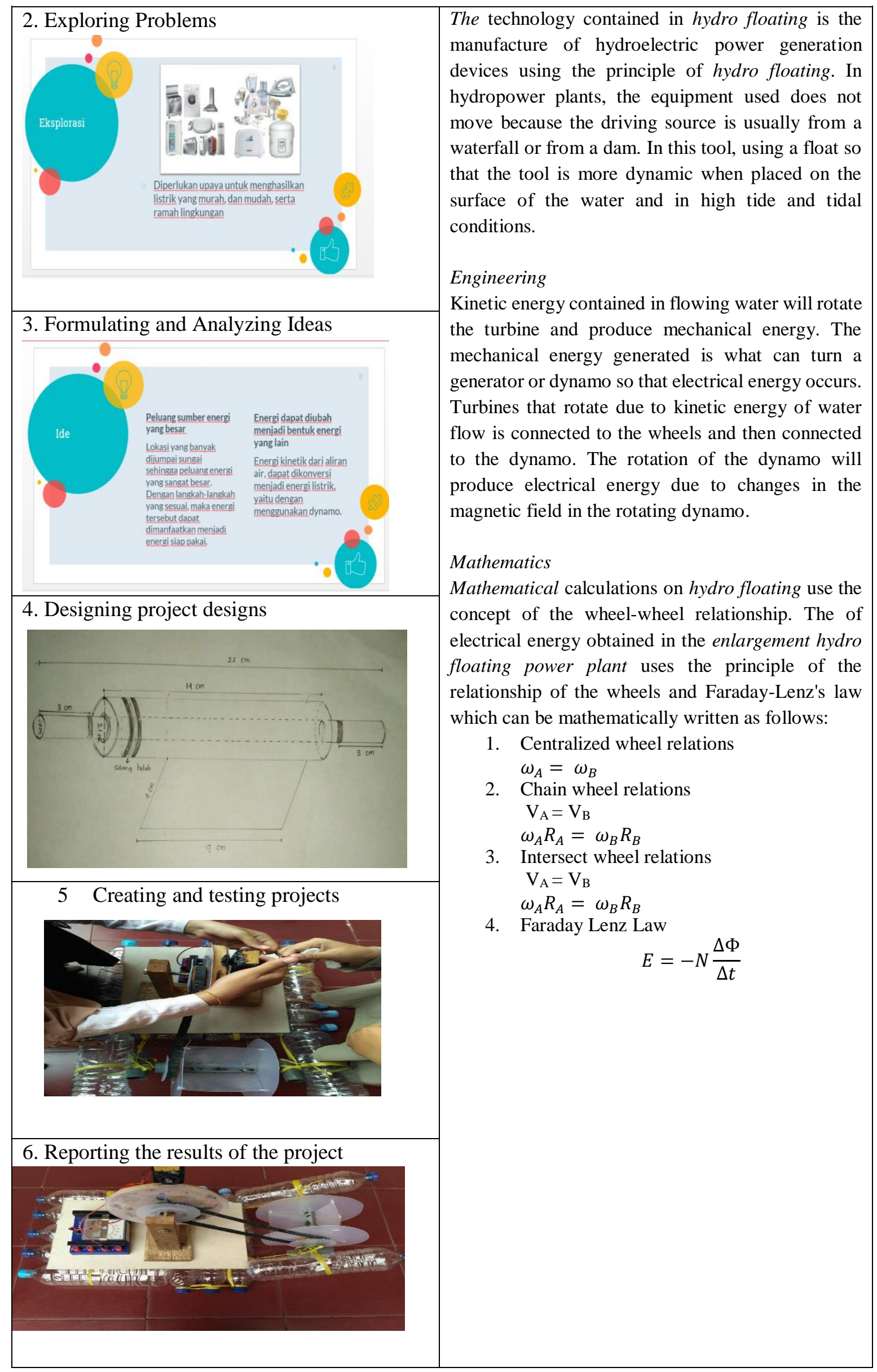


Table III explains that the dimensions of student creativity is developed well through the integration of STEM knowledge. The increase of student creativity is a learning process activity to jointly solve problems that are in accordance with the four pillars of education, namely learning to know, learning to do, learning to be, and learning to live together [14]. The level of student creativity based on the dimensions of creativity are grouped into four elements which are often called the 4P component consisting of Person, Process, Product, and Press [15 - 16, 13]. Human characteristics as individuals must have a sense, work, creativity that involves personality, motivation, intelligence, thinking style, emotional intelligence, and knowledge [17].

TABLE IV. T-TEST RESULTS OF 4P STUDENT CREATIVITY DIMENSION

\begin{tabular}{|l|l|c|c|}
\hline \multicolumn{1}{|c|}{ Subject } & \multicolumn{1}{|c|}{ Pre-test/Pos-test } & Paired Differences M (SD) & t \\
\hline Person & Pair 1 & 8.25 & $6.05^{* * *}$ \\
\hline & Per-pPer & $(7.36)$ & $10.15 * * *$ \\
\hline Process & Pair 2 & 14.54 & \\
\hline & Pro-pPro & $(7.71)$ & $23.51 * * *$ \\
\hline Product & Pair 3 & 18.22 & $7.11 * * *$ \\
\hline & Prd-pPrd & $(4.10)$ & \\
\hline Press & Pair 4 & $(9.53)$ & \\
\hline & Pre-pPre $p<0.05, * * p<0.01, * * * p<0.001$ & &
\end{tabular}

The data shows that the students experienced a significant change in all components of the $4 \mathrm{P}$ creativity dimension as seen in Table IV. The component Product $(\mathrm{t}=23.51, \mathrm{p}$ $<0.001)$ experienced the biggest change, then the component Process $(\mathrm{t}=10.15, \mathrm{p}<0.001)$, the Press component $(\mathrm{t}=7.11$; $\mathrm{p}<0.001)$, and the smallest change lies in the Person component $(\mathrm{t}=6.05 ; \mathrm{p}<0.001)$.

Based on these results, it can be stated that the learning process through the integration of STEM knowledge can increase the dimensions of student creativity effectively. In addition, the learning process through STEM integration is able to create a learning environment that encourages students to explore the dimensions of creativity to the fullest.

\section{CONCLUSION}

Creativity competence is one of the competencies students must master in 21st-century learning. This study aims to explore the dimensions of student creativity through the integration of STEM knowledge. Based on the results and discussion above, it can be concluded: (a) The learning process through the integration of STEM knowledge can improve student creativity in terms of creative thinking abilities consisting of fluency, flexibility, originality, and elaboration; and (b) The learning process through the integration of STEM knowledge can increase the dimensions of student creativity components of the dimensions of creativity consisting of Person, Process, Product, and Press.

\section{REFERENCES}

[1] P. Häkkinen, S. Järvelä, K. Mäkitalo-Siegl, A. Ahonen, P. Näykki, and T. Valtonen, "Preparing teacher-students for twenty-first-century learning practices (PREP 21): a framework for enhancing collaborative problem-solving and strategic learning skills," Teachers and Teaching, vol. 23(1), pp. 25-41, 2017.

[2] D.H. Autor, F. Levy, and R. J. Murnane, "The skill content of recent technological change: An empirical exploration," The Quarterly journal of economics, vol. 118(4), pp. 1279-1333, 2003.

[3] K. Illeris, N. Katznelson, B. Simonsen and L. Ulriksen, "Ungdom, identitet o uddannelse,", 2003.

[4] M. V. Bøe, E. K. Henriksen, T. Lyons and C. Schreiner, "Participation in science and technology: young people's achievement-related choices in late-modern societies," Studies in Science Education, vol. 47(1), pp. 37-72, 2011.

[5] K. N. Marambe, J. D. Vermunt and H. P. Boshuizen, “A cross-cultural comparison of student learning patterns in higher education," Higher Education, vol. 64(3), pp. 299-316, 2012.

[6] J.J. Kuenzi, Science, technology, engineering, and mathematics (STEM) education: Background, federal policy, and legislative action, 2008.

[7] K. Becker and K. Park, "Effects of integrative approaches among subjects on students' learning: A preliminary meta-analysis", Journal of STEM Education: Innovations \& Research, vol. 12, 2011.

[8] S. J. Lou, C.C. Chung, W. Y. Dzan, K. H. Tseng, and R. C. Shih, "Effect of using TRIZ creative learning to build a pneumatic propeller ship while applying STEM knowledge," International Journal of Engineering Education, vol. 29(2), pp. 365-379, 2013.

[9] R. E. Peterson, "Establishing the creative environment in technology education: Creativity doesn't just happen by chance; the prepared environment nourished it," The Technology Teacher, vol. 61(4), pp. 7-11. 2001.

[10] J. W. Creswell and P.V.L. Crack, Designing and Conducting Mix Method Research, London \& New Delhi: Sage Publication, 2007.

[11] C. H. Lawshe, "A quantitative approach to content validity 1," Personnel psychology, vol. 28(4), pp. 563-575, 1975.

[12] J. P. Guilford, Way beyond the IQ. Buffalo, NY: Creative Education Foundation, 1977.

[13] M. Rhodes, "An analysis of creativity," The Phi Delta Kappan, vol. 42(7), pp. 305-310, 1961.

[14] A. Smith, The influence of education on conflict and peace building, Background paper prepared for the Education for All Global Monitoring Report 2011 The Hidden Crisis: Armed conflict and education, Paris: UNESCO, 2010.

[15] E. L. Santanen, R. O. Briggs and G. J. de Devreede, "Towards an understanding of creative solution generation," In Proceedings of the 35th Annual Hawaii International Conference on System Sciences (pp. 2899-2908), January 2002.

[16] L.L. Davis, "Instrument review: Getting the most from a panel of experts," Applied nursing research, vol. 5(4), pp. 194-197, 1992.

[17] J. C. Kaufman and R. J. Sternberg, The international handbook of creativity, Cambridge University Press, 2006. 